\title{
THE RESEARCH ON THE CONSTRUCTION OF NINGBO CHINA-CEE TECHNOLOGY TRANSFER PLATFORM
}

\author{
Danjuan Hu \\ Ningbo University of Technology, Ningbo, Zhejiang, China \\ Bo Wang \\ Ningbo University of Technology, Ningbo, Zhejiang, China \\ CMESTE \\ JEL Category: L24, 014
}

\begin{abstract}
Through the research on the construction of China-CEE technology transfer platform, this paper puts forward the corresponding measures and suggestions for the current status and existing problems of the platform at the present stage. At the same time, by the analysis of the demand of social and economic development of Ningbo for the technology transfer platform, fill the blank area of Ningbo in the research on the construction of China-CEE technology transfer platform, thus to offer scientific basis to the relevant decisions of government department, guide and form the public service system which adapts to the demand of technology transfer and the demand of social and economic development with an overall layout, resource sharing, perfect function and efficient operation, promote the formation of efficient China-CEE technology transfer platform, strengthen the international science and technology cooperation and exchange with the countries of CEE and CIS, enable the deep promotion of the strategic fulcrum city construction of "One Belt and One Road" of Ningbo, and accelerate the integration and service for the national strategy of "One Belt and One Road".
\end{abstract}

Key words: China-CEE; technology transfer; platform; construction.

\section{INTRODUCTION}

\subsection{Research background}

Along with the continued growth of China's economy, and the deepening of "One Belt and One Road" strategy, the cooperation between China and CEEC in various fields and levels shows an accelerating trend. As the main node

Address of the corresponding author:

Danjuan Hu

表=- arieshu@126.com city of national " One Belt and One Road" project, Ningbo takes the advantages of its location, port and opening to constantly expand the cooperation with CEEC, focusing on creating the central city of China-CEEC "One Belt and One Road" cooperation, serving the full cooperation with China-CEEC, promoting the cooperation and development between China and 16 countries of CEE.

The Government of Ningbo Municipality came up with Several Opinions on Strengthening overall cooperation with Central and Eastern European 
Countries in 2015, and holds China-CEE conference regularly every year, gradually building up the normalization cooperation mechanism, giving full play to the role of the national strategic fulcrum city of "One Belt and One Road". Since Ningbo has become the first batch of national innovation-type pilot cities in 2010, it has become the first pilot demonstration city nationwide of "Made in China 2025" in succession and one of the first batch of two scientific and technological achievements transfer and transformation demonstration areas nationwide, which will certainly accelerate the pace of science and technology innovation and development of Ningbo.

\subsection{The meaning of research}

Put forward the relevant measures and suggestions on the status quo and existing problems of technology transfer platforms at the present stage through the research on the construction of China-CEE technology transfer platform. Meanwhile, through the analysis of the needs of social and economic development of Ningbo for technology transfer platform, fill the blank area in the research of the construction of China-CEE technology transfer platform of Ningbo thus to offer scientific basis to the relevant decisions of government department, guide and form the public service system which adapts the demand of technology transfer and the demand of social and economic development with an overall layout, resource sharing, perfect function and efficient operation, promote the formation of efficient China-CEE technology transfer platform

The wave of the construction of "One Belt and One Road" has made the technology transfer activities between China and CEE increasingly active and the connection of technology, resources and talent between both sides or multiple sides increasingly frequent. Through the research on the construction of China-CEE technology transfer platform, further strengthen international cooperation in science and technology exchanges between China and CEE and CIS countries while at the same time forming the efficient technology transfer platform, which can effectively promote the construction of strategic fulcrum city of Ningbo of " One Belt and One Road ", and accelerate the integration and service for the national strategy of " One Belt and One Road ".

\section{THE CHARACTERISTICS AND DEVELOPMENT TREND OF TECHNOLOGY TRANSFER PLATFORM AT HOME AND ABROAD.}

\subsection{The characteristics and development trend of technology transfer platform at home and abroad.}

The US technology transfer policy is made around the progress and development of technology transfer to improve the economic benefits of technology transfer. The key is to promote technology transfer of public achievements. The main sources of public technology are federal laboratories and universities. In 1974, the Federal Laboratory Technology Transfer Consortium (FLC) was established in the United States. In 1980 the promulgated "Bayh Dole Act" allows the university to own the intellectual property rights of research achievements funded by government. The "Intellectual Property Rights Optimization Resources and Organization Act" was promulgated in October, 2008 to improve the efficiency of the US government in protecting intellectual property rights, such as copyright, patent, trademark and so on. Compared with the United States, Japan's technology transfer is characterized by: government policy guidance and legal enforcement combined, based on IndustryUniversity-Research cooperation, technology transfer focuses on promoting the flow of talent and the patent transfer development. European technology transfer is characterized by the emphasis on technology transfer service network construction, such as the establishment of an allEuropean technology platform, the establishment of national and regional and European scientific and social activity networks, and the European Union's Innovation Relay Centre (RC), which has a high level of specialization in technology transfer service. Medium and small enterprises have the weakest R\&D strength but have the strongest demand for technology transfer of public technology achievements. Therefore, major developed countries all pay attention to the transfer technology from research institutes and universities to medium and small enterprises, and have specially formulated technology transfer plans for medium and small enterprises. (Zheng, Huang, \& Hou, 2009) 


\subsection{The characteristics and development trend of domestic technology transfer platform}

\subsubsection{Laws and policies on technology transfer in China}

Since the policy of Reform and Opening-up, China has made great progress in the construction of laws and regulations related to technology transfer while continuously expanding technology transfer. China has established a relatively thorough system of relevant policies and regulations at present.

The promulgation of relevant laws and regulations on technology transfer in China marks the gradual maturity of China's technology transfer. China's "World Factory" from the beginning of Reform and Opening-up has gradually begun to shift to the "Research and Development Center", starting from "Made in China" to "Creation in China". (Chenhai \& Peizhong., 2007)

Table 1 Promulgation schedule of laws and regulations relating to technology transfer

\begin{tabular}{|c|c|}
\hline Time/year & Promulgation of laws and regulations relating to technology transfer \\
\hline 1993 & $\begin{array}{l}\text { Law of the People's Republic of China on Progress of Science and Technology (Revised } \\
\text { Draft) }\end{array}$ \\
\hline 1996 & $\begin{array}{l}\text { Law of the People's Republic of China on Promoting the Transformation of Scientific and } \\
\text { Technological Achievements }\end{array}$ \\
\hline 1999 & Contract Law of the People's Republic of China \\
\hline 2006 & Opinions on Accelerating the Development of Technology Market \\
\hline 2007 & $\begin{array}{l}\text { Measures for the Administration of National Technology Transfer Demonstration } \\
\text { Institutions, National Technology Transfer Promotion Action Implementation Plan }\end{array}$ \\
\hline 2015 & $\begin{array}{l}\text { Several Opinions of the CPC Central Committee and the State Council on Deepening the } \\
\text { Reform of System and Mechanism and Accelerating the Implementation of Innovation- } \\
\text { driven Development Strategy }\end{array}$ \\
\hline 2016 & $\begin{array}{l}\text { National Innovation Drives Development Strategy Outline, Several Provisions of } \\
\text { Implementation of the "Law of the PRC on Promoting the Transformation of Scientific and } \\
\text { Technological Achievements", Action Plan of Promoting the Transfer and Transformation } \\
\text { of Scientific and Technological Achievements, Several Opinions on Strengthening the } \\
\text { Transfer and Transformation of Science and Technology Achievements in Colleges and } \\
\text { Universities, Guiding Opinions of The Chinese Academy of Sciences on Accelerating the } \\
\text { Transfer and Transformation of Scientific and Technological Achievements }\end{array}$ \\
\hline 2017 & $\begin{array}{l}\text { Construction of the National Scientific and Technological Achievements Transfer } \\
\text { Transformation Demonstration Zone Implementation Plan of Zhejiang Province (2016- } \\
\text { 2020), Implementation Plan of Construction of the National Scientific and Technological } \\
\text { Achievements Transfer Transformation Demonstration Zone of Ningbo City }\end{array}$ \\
\hline
\end{tabular}

2.2.2 The mode of technology transfer in China

According to the differences of degree of involvement of participant and the radiation range of technology transfer in the technology transfer activity, the mode of technology transfer in China is divided into five categories as shown in Table 2. 
Table 2 The table of the mode classification of technology transfer

\begin{tabular}{|c|c|c|}
\hline \multicolumn{2}{|c|}{ The mode of technology transfer } & Characteristic analysis \\
\hline $\begin{array}{l}\text { Traditional } \\
\text { transfer }\end{array}$ & mode of technology & $\begin{array}{l}\text { The scale of cooperation and sum of technology transaction } \\
\text { are generally small when the achievements of scientific } \\
\text { research are transmitted directly from universities to } \\
\text { enterprises. It is suitable for the R\&D and technology transfer } \\
\text { for the technology with good foundation or good market } \\
\text { prospect. }\end{array}$ \\
\hline Technology I & censing mode & $\begin{array}{l}\text { This mode has a fast transformation and is efficient and } \\
\text { suitable for comparatively mature applied technology. }\end{array}$ \\
\hline \multicolumn{2}{|c|}{ Cooperative $R \& D$ mode } & $\begin{array}{l}\text { This model promotes the complementary advantages and } \\
\text { comprehensive cooperation between local and universities, } \\
\text { and the research achievements of cooperative R\&D mode } \\
\text { are high in quality, the substitution of which is not strong, } \\
\text { longer time-consume, the future benefits are high, and the } \\
\text { risks are high. }\end{array}$ \\
\hline \multirow{4}{*}{$\begin{array}{l}\text { Technology } \\
\text { incubator } \\
\text { mode }\end{array}$} & $\begin{array}{l}\text { Taking the Science and } \\
\text { Technology Park of the } \\
\text { university as the } \\
\text { management } \\
\text { organization }\end{array}$ & $\begin{array}{l}\text { It is convenient and fast to communicate with technological } \\
\text { information, personnel and other factors of technology } \\
\text { transfer, and the success rate of achievement transformation } \\
\text { is high; the dependence on operating capital, human } \\
\text { resources and technology aspect is strong. It is suitable for } \\
\text { comprehensive technology with strong systematism and high } \\
\text { level. }\end{array}$ \\
\hline & $\begin{array}{l}\text { Taking the National-level } \\
\text { Research Institution as } \\
\text { the management } \\
\text { organization }\end{array}$ & $\begin{array}{l}\text { The policy is superior, the fund is abundant, and research } \\
\text { ability in in the field of basic science is strong. It is suitable to } \\
\text { the technology with fundamentality or generality in the field of } \\
\text { key technology science. }\end{array}$ \\
\hline & $\begin{array}{l}\text { Taking the cooperation } \\
\text { research institute of } \\
\text { provincial (municipal) } \\
\text { college as the } \\
\text { management } \\
\text { organization }\end{array}$ & $\begin{array}{l}\text { It can rely on the university's scientific research strength and } \\
\text { the resource advantages, can obtain the certain start fund } \\
\text { from the local government, the office space and the policy } \\
\text { support. It is suitable for the applied technology which accord } \\
\text { with the demand of local development. }\end{array}$ \\
\hline & $\begin{array}{l}\text { Taking the Associated } \\
\text { Research and } \\
\text { Development Agency of } \\
\text { college-enterprise as the } \\
\text { management } \\
\text { organization }\end{array}$ & $\begin{array}{l}\text { Strong market pertinence, short the transfer cycle and high } \\
\text { success rate. The requirement for enterprise's active initiative } \\
\text { and capital investment requirements is higher. It is suitable } \\
\text { for the industry leading applied technology. }\end{array}$ \\
\hline \multirow{3}{*}{$\begin{array}{l}\text { Technology } \\
\text { transfer } \\
\text { platform } \\
\text { mode }\end{array}$} & $\begin{array}{l}\text { Taking the University } \\
\text { and } \\
\text { Cooperation Committee } \\
\text { as the platform }\end{array}$ & $\begin{array}{l}\text { The technology transfer service is diversified, and market } \\
\text { pertinence is strong, and the channel of information } \\
\text { communication is smooth; the independence of the } \\
\text { cooperation committee institution is poor, and the market } \\
\text { orientation is remarkable. It is suitable for high level and cross } \\
\text { field scientific research achievements which is applicable to } \\
\text { colleges and universities. }\end{array}$ \\
\hline & $\begin{array}{l}\text { Taking the Cooperation } \\
\text { Office of industry- } \\
\text { university-research as } \\
\text { the platform }\end{array}$ & $\begin{array}{l}\text { Information is smooth, funds are in place, and cooperation is } \\
\text { close; the participation of enterprises is not high, and market } \\
\text { demand is not easy to grasp. It is suitable for high-level cross- } \\
\text { disciplinary scientific research achievements which is } \\
\text { applicable to colleges and universities. }\end{array}$ \\
\hline & $\begin{array}{l}\text { Taking the technology } \\
\text { transfer center as the } \\
\text { platform }\end{array}$ & $\begin{array}{l}\text { The operation is in marketization, the channel of the source } \\
\text { of technology and the transferred objects are relatively } \\
\text { dispersed; lack a complete management institutional system. } \\
\text { It mainly targets the promotion and industrialization apply of } \\
\text { existing scientific and technological achievements. (Jinyi, } \\
\text { 2012) }\end{array}$ \\
\hline
\end{tabular}




\subsubsection{China's technology transfer platform presents a trend of cooperation and co-construction}

Regarding the construction of technology transfer platform, it currently presents a trend of cooperation and co-construction. For example, the construction of public information platform for technology transfer in three provinces of Northeast China has become a public service information platform and service system for regional technology transfer covering the northeast and serving the whole country. The "Union of Technology Transfer of Circum-Bohai-
Sea" was founded by Technology Market Management Department of 6 provinces and cities such as Beijing, Tianjin, Hebei, Shanxi, Inner Mongolia, Liaoning, Shandong province. Science and Technology Commission Shanghai Municipality, Science Technology Department of Jiangsu province, Science Technology Department of Zhejiang province signed Joint Trade Agreement on Regional Cooperation to ensure the full flow of elements of innovation such as information, finance, talents, achievements and technology.

Table3 China-CEE Cooperation Exchange Event Table

\begin{tabular}{|c|c|c|}
\hline Time & Event & Content \\
\hline June 8, 2015 & $\begin{array}{l}\text { Zhejiang International } \\
\text { Matchmaking Meeting for } \\
\text { Technology } \quad \text { Transfer } \\
\text { Projects } \quad \text { (Zhejiang } \\
\text { Investment \& } \quad \text { Trade } \\
\text { Symposium) }\end{array}$ & $\begin{array}{l}\text { Representatives of } 22 \text { scientific research institutions or } \\
\text { enterprises from } 9 \text { countries including Germany, Japan and } \\
\text { Russia brought } 124 \text { projects of scientific and technological } \\
\text { achievements to negotiate and dock with hundreds of } \\
\text { representatives in China, enabling domestic enterprises } \\
\text { understand the international frontier of industrial technology and } \\
\text { discover the potential cooperative partner. }\end{array}$ \\
\hline $\begin{array}{l}\text { June } 8-12 \\
2015\end{array}$ & $\begin{array}{l}\text { China-CEEC Investment } \\
\text { and Trade Expo }\end{array}$ & $\begin{array}{l}\text { Held the series of activities such as investment negotiation, } \\
\text { exhibition transaction, conference, cultural exchanges and so on, } \\
\text { which are all around the strategies of "One Belt and One Road" } \\
\text { and Yangtze River Economic Belt and based on the theme of } \\
\text { "expanding open cooperation and building the One Belt and One } \\
\text { Road together". }\end{array}$ \\
\hline $\begin{array}{l}\text { June } \\
2015\end{array}$ & $\begin{array}{l}\text { China (Ningbo) -CEEC } \\
\text { Investment Cooperation } \\
\text { Industrial Park Promotion } \\
\text { Conference }\end{array}$ & $\begin{array}{l}\text { Promote two-way cooperation between Ningbo and CEEC, to help } \\
\text { more enterprises of Ningbo and CEEC understand the investment } \\
\text { climate and relevant policies of the industrial parks of both sides, } \\
\text { and to promote the two-way investment of "Bring In and Go Out" } \\
\text { between Ningbo and CEEC. }\end{array}$ \\
\hline $\begin{array}{l}\text { June } \\
2016\end{array}$ & $\begin{array}{l}\text { China-CEEC Investment } \\
\text { Cooperation Meeting }\end{array}$ & $\begin{array}{l}\text { Help Chinese enterprises have a targeted understanding about } \\
\text { the market condition of CEE and the key investment industry, and } \\
\text { set up an effective platform for communication, negotiation and } \\
\text { docking with CEEC, and improve the convenience of foreign } \\
\text { investment for Chinese enterprises, which based on the theme of } \\
\text { "Going Out of Financial Services". }\end{array}$ \\
\hline June 9, 2017 & $\begin{array}{lr}\text { China (Ningbo) } & \text {-Central } \\
\text { and Eastern } & \text { European } \\
\text { Country } & \text { S\&T } \\
\text { Achievements } & \text { Promotion } \\
\text { Meeting }\end{array}$ & $\begin{array}{l}\text { Experts from } 7 \text { countries including Ukraine, Bulgaria, the Czech } \\
\text { Republic and Slovakia took } 19 \text { scientific and technological } \\
\text { achievements to "date" on scene and conducted technical } \\
\text { exchange docking in technological markets with representatives } \\
\text { from more than } 40 \text { enterprises of Ningbo to deepen the potential } \\
\text { for cooperation and promote the cooperation between each other. }\end{array}$ \\
\hline
\end{tabular}


3 THE CURRENT STATUS AND EXISTING PROBLEMS OF THE CONSTRUCTION OF NINGBO CHINA-CEE TECHNOLOGY TRANSFER PLATFORM

\subsection{The current status}

\subsubsection{Technical Achievement Exhibition}

Since the "16+1 Cooperation" came into being in April 2012, for five years, the relations between China and CEE have been continuously deepened and developed, presenting a fine development trend which is all-round, wideranging and multi-level.
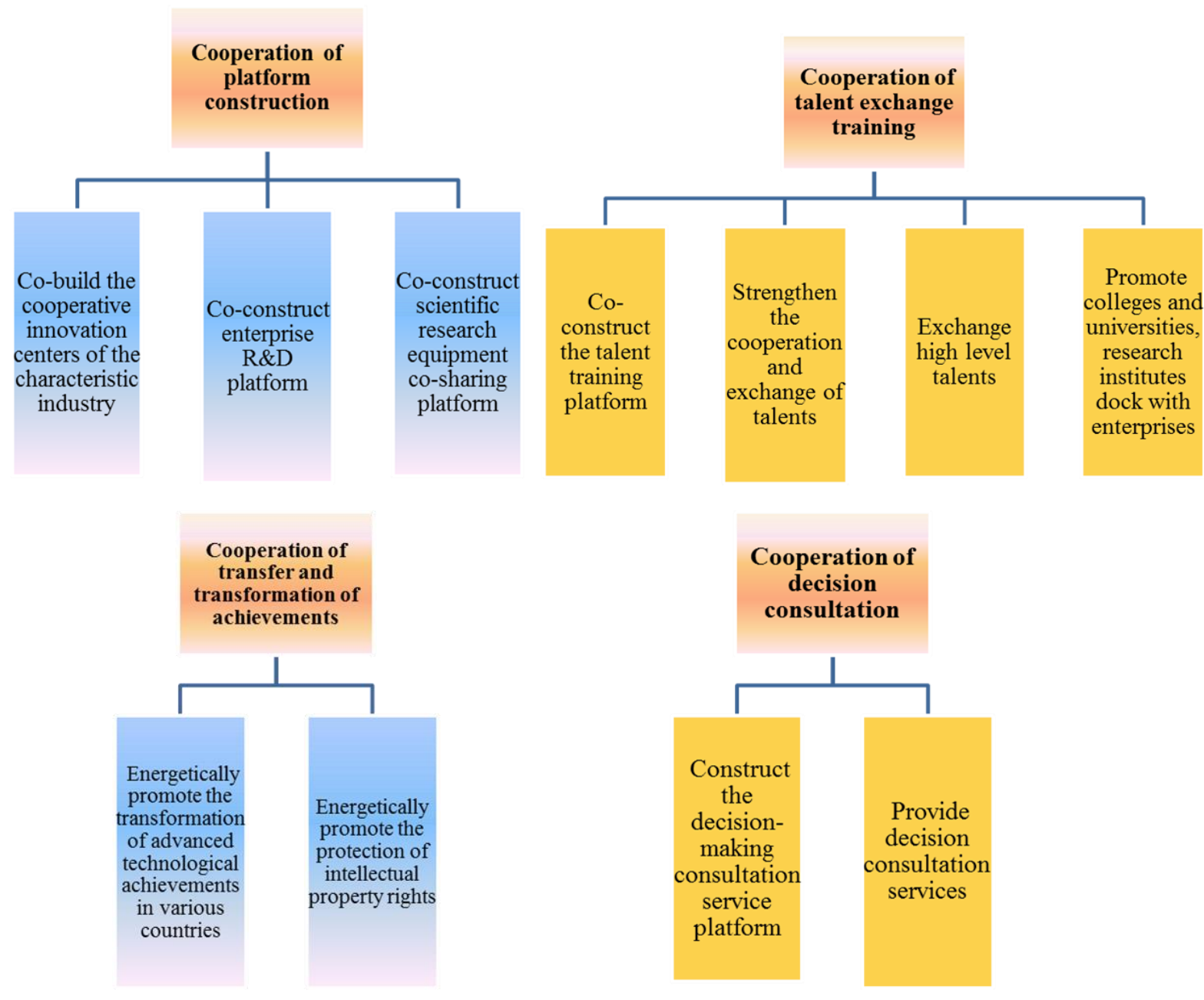

Fig. 1 Graphic scheme of four aspects of cooperation

\subsubsection{Build the CEE (Ningbo) Industrial Park}

Under the background of the "One Belt and One Road" initiative, Ningbo, as the central city of

\subsubsection{Prepare to build China-CEE International Scientific and Technological Innovation Achievements Transfer Center and build bridge of technology transfer}

In 2016, China-CEEC Education Conference and Expo was held in Ningbo, scientific research institutions of four colleges, which are Ningbo University of Technology, Todor Kableshkov University of Transport, University of Žilina, Space Research and Technologies Institution of Bulgarian Academy of Sciences, reached the cooperation intention and signed Cooperation Memorandum of the preparation to build ChinaCEE International Scientific and Technological Innovation Achievements Transfer Center. The transfer center carried out the cooperation in four areas, as shown below: 
Central and Eastern European (Ningbo) Industrial Park strongly promoted the two-way cooperation and the two-way investment of "Bring In and Go Out" between Ningbo and CEEC. The industrial park focused on the introduction of high valueadded industries such as high-tech machinery manufacturing, electronic information, environment protection equipment, auto parts, specialty textiles and cultural creativity in CEE through technology transfer, cooperative R\&D, project introduction and other means. Meanwhile, accept the transfer of technology, talents, management and funds from outstanding enterprises in CEE and cooperate to carry out technology R\&D.

\subsection{Problems}

In recent years, significant achievements have been made in technology transfer between Ningbo and CEE. However, due to the relatively late start of technology cooperation between Ningbo and CEE and China has not systematically established the China-CEE Technology Transfer Center in the whole, the technology transfer is short of good institutions, mechanisms and policies. In the following, the existing problems in the current construction of the China-CEE technology transfer platform in Ningbo will be introduced from three aspects.

\section{(1) The support for setting up technology transfer platforms still needs to be increased}

As the first batch of innovative polit cities in China, Ningbo will always strengthen the science and technology cooperation with CEE and build Ningbo China-CEE technology transfer platform as a strategic development goal. An environment for technology transfer has been created by formulating and implementing a series of laws and policies related to technology transfer. However, due to the fact that these laws and policies related to technology transfer are still in a decentralized condition and lack a legal document focusing on technology transfer and system which leads to the relevant stakeholders, division of labor and the end of property rights in the process of technology transfer are all uncertain. Moreover, the government departments at all levels have attached insufficient importance to the establishment of CEE technology transfer platform and have insufficient support on human and financial resources. Besides, the funds of R\&D have not been fully implemented.

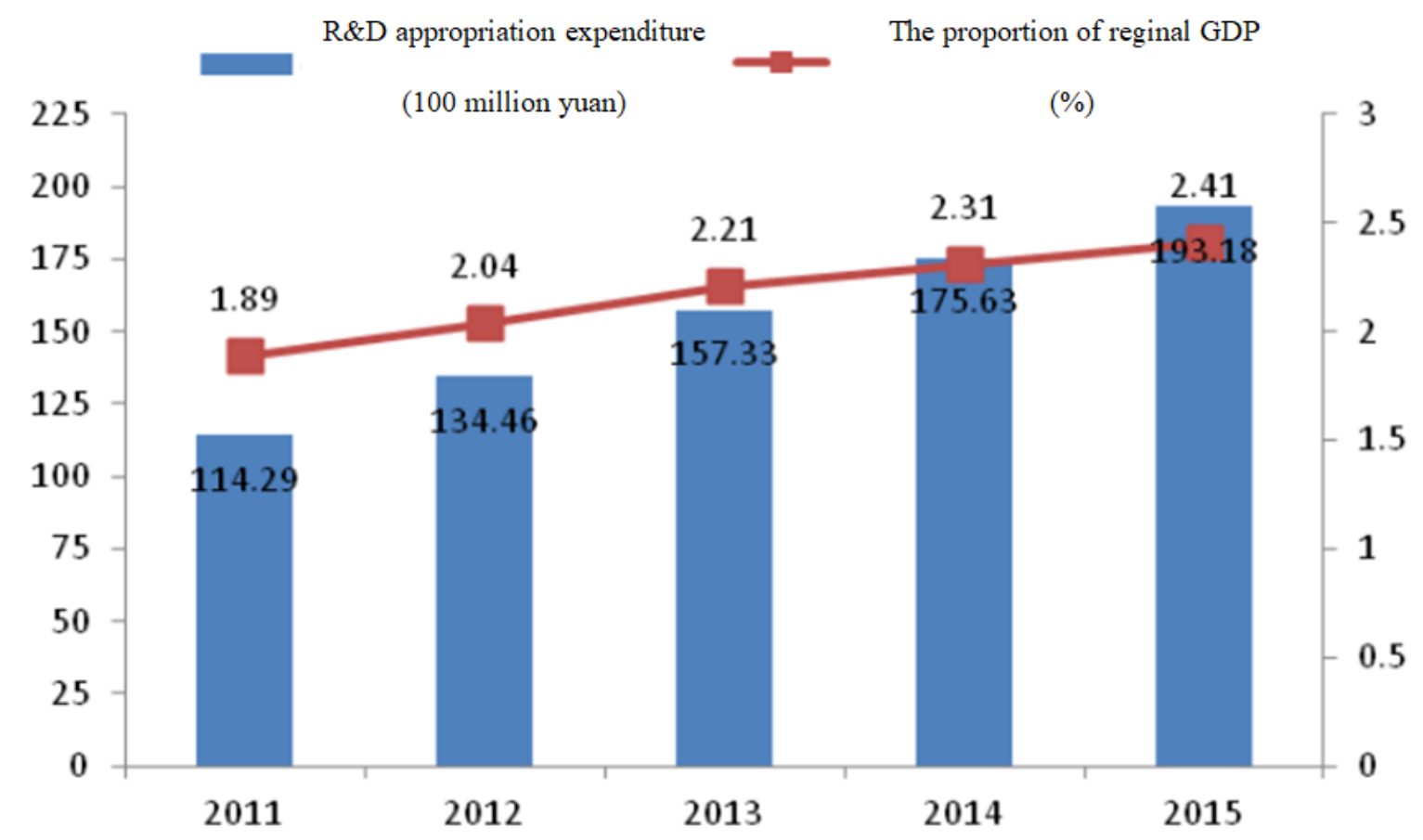

Fig. 2 The appropriation expenditure of R\&D in Ningbo and proportion of reginal GDP (2011-2015) 


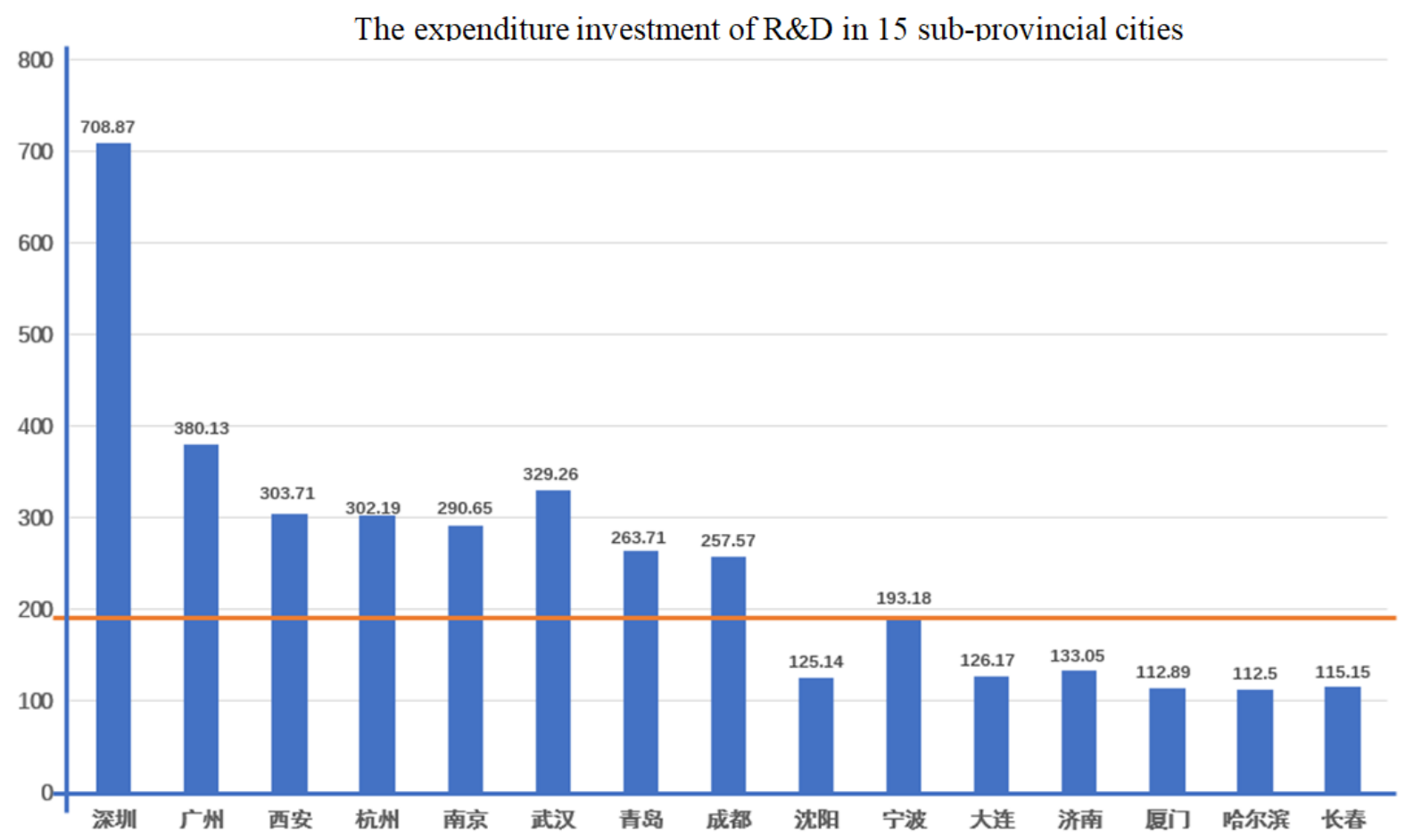

Fig. 3 The expenditure investment of R\&D in 15 sub-provincial cities in 2015

Figure 2 shows that the appropriation expenditures of R\&D in Ningbo are increasing every year but there is still a large gap between the appropriation expenditures of R\&D in Ningbo compared with other cities (for example, figure 3 ).

(2) The exchange of supply and demand information for technology transfer is poor, the success rate is low

There are two reasons for the low success rate of technology transfer. On the one hand, it is due to the difference in language environment with CEEC, resulting in poor communication and exchange of supply and demand information for technology transfer, and difficulty in the docking between supply and demand. On the other hand, the technology transfer platform does not have comprehensive and accurate information on the supply and demand two sides, and the feedback on the enterprise's information demands is not timely. But the main reason is that there is not enough docking between the scientific research institutions as the source of technology and colleges and universities and enterprises.

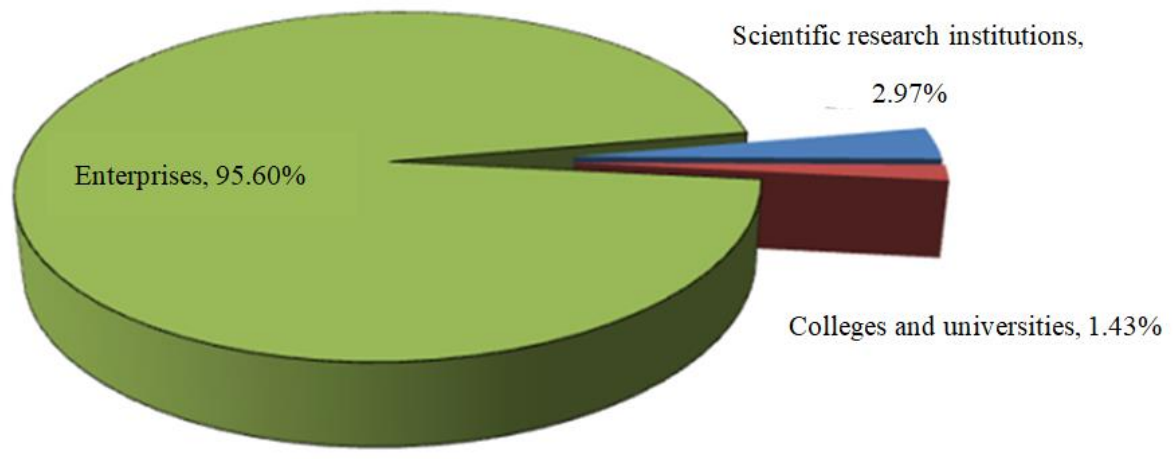

Fig. 4 R\&D expenditures of Ningbo City in 2015 classified according to executive department

From the perspective of current R\&D expenditures institutions and colleges and universities is less of Ningbo's executive departments (Fig. 4), 95.60\% than 5\%, thus making the docking between of R\&D expenditures are paid by enterprises, enterprises and scientific research institutions, while the total share of scientific research enterprises and colleges and universities are 
difficult to reflect. This ultimately leads to the scientific research institutions' projects and achievements are difficult to make accurate position of the market, the degree of technology transfer docking is low, the scientific and technological achievements of colleges and universities and scientific research institutions can't be quickly transformed, the enterprise's technological demands can't be satisfied, the emergence of scientific research repetition and waste and other phenomena.

\section{(3) Lack of high-end technology brokers}

Technology transfer is different from ordinary commodity trading in that it has greater complexity and higher risks, and therefore requires higher quality of technical brokers. An excellent technology broker, he must be a compound talent, understand not only technology, but also manage and coordinate, at the same time, he also has the quality and ability of technical experts, entrepreneurs, social activists. However, at present, most of the people engaged in technology transfer work in Ningbo are experienced talents, and their professional capabilities are insufficient. Therefore, high-end technology brokers in the technology transfer talent team can't meet the requirements of rapid industrial development.

\section{DEMAND ANALYSIS FOR TECHNOLOGY TRANSFER PLATFORM IN NINGBO'S FUTURE SOCIAL ECONOMIC DEVELOPMENT}

With the rapid economic and social development in Ningbo, the demand for technology transfer from all walks of life presents a continuous growth and multi-level and diversified features. In 2016, Ningbo's economy maintained a strong momentum of development, achieving a GDP of 854.11 billion yuan, an increase of $7.1 \%$ over the previous year. According to the "The Thirteenth Five-Year Plan" of Ningbo City, Ningbo will promote the integration development of informatization and industrialization, manufacturing and service industries, enhance the development of five manufacturing industries with traditional advantages, cultivate new industries, support the production services industry, and accelerate the development of smart economy.



Fig. 5 Ningbo's GDP in 2011-2016

For a long time, the biggest obstacle to restricting the rapid transfer of technological innovation achievements is the lack of a good system, mechanism, policy environment, and service platform for domestic technology transfer. To effectively integrate scientific and technological resources, save innovation costs, speed up the flow of knowledge, transform of scientific and technological achievements, and enhance the competitiveness of regional economies, at present, creating a service platform that is conducive to the rapid transfer of technological achievements is an imperative and an urgent task. 
4.1 Needs for co-building joint laboratory (joint research center)

The transfer and transform of technological achievements can ' $t$ be separated from the longterm and stable partnership. At present, the cooperation between colleges and universities, scientific research institutes and countries along the route in Ningbo is not stable, and there is a shortage of composite talents who understand both technology and management. Therefore, it is urgent to promote the co-building of the joint laboratory. In conjunction with the major scientific and technological demands of countries along the route, we must co-build the joint laboratory (joint research center) in key fields, jointly promote highlevel scientific research, conduct exchange and training of scientific and technological talents, promote the transfer of applicable technologies and transform of achievements, and build longterm stable partnership, enhance the scientific and technological capabilities of countries along the route.

\subsection{Needs for co-building a Technology Transfer Center by Colleges and Universities, Scientific Research Institutions}

Through investigations, it is found that the work of the technology transfer management department responsible for the unit determines to a large extent whether the technology transfer work of colleges and universities, scientific research institutions in Ningbo is effective. The "National Implementation Plan for Technology Transfer Promotion" clearly states that it is necessary to strengthen the integration of the technology transfer system of scientific research institutions, support the establishment of a special technology transfer institution, and take full responsibility for the technology transfer work of the unit. Therefore, colleges and universities, scientific research institutions should speed up the co-building of the technology transfer center, improve the construction of technology transfer coordination networks and information docking platforms, encourage technology transfer centers to build international technology transfer service alliances, jointly promote the transfer of advanced and applicable technologies, and deepen IndustryUniversity-Research cooperation.

\subsection{The demand to co-build the base of demonstration and promotion of advanced applied technology.}

The supply of advanced applied technology in Ningbo is insufficient to keep up with the demand for the development of leading industries and pillar industries, which is becoming one of the "bottlenecks" of a new round of economic and social development of Ningbo. The promotion of advanced applied technology in key areas has been dispersed in the related platforms such as the system of industry-university-research cooperation, municipal scientific research institutions, municipal high and new colleges and enterprises. It is necessary to further highlight and intensify the functions of advanced applied technology in the construction of the above related platforms to co-build the base of demonstration and promotion of advanced applied technology. (Zheng, Huang, \& Hou, 2009)

\section{MEASURES AND SUGGESTIONS FOR THE CONSTRUCTION OF $\begin{array}{lr}\text { NINGBO } & \text { CHINA-CEEC } \\ \text { TECHNOLOGY } & \text { TRANSFER }\end{array}$ PLATFORM}

\subsection{Perfect laws and regulations and improve the market environment}

As China now is at the primary stage of socialism, various items of laws and regulations are not perfect. In order to establish the mechanism of technology transfer promotion, we must speed up the reform of science and technology system. Improve the protection policies of intellectual property rights, and the laws and regulations of various patent laws and scientific research laws, etc. to protect intellectual property rights, adjust the various relations in the technology transfer; improve and reform other aspects of the policy and formulate many-sided policies and measures such as finance, banking, taxation, technology and incentives to form a relatively complete policy system that encourages technology development and technology transfer and protection of intellectual property rights.

\subsection{Encourage innovation multiparty win-win. \\ technology achieve}

The government should increase the investment 
of R\&D funds, encourage enterprises to innovate, and encourage the enthusiasm of enterprises and scientific researchers through preferential measures such as tax and subsidies to fully promote the improvement of capability of technological absorption and innovation. At the same time, we should broaden the channels of technical transaction and re-financing, speed up the establishment of a technological innovation system based on enterprise as the main body, market oriented and industry-university-research combined, build the common technology R\&D services platform and the transformation platform of scientific and technological achievements, and promote the cooperation of industry-universityresearch. In addition, the training of advanced professional talents in technology transfer should be sped up and cultivate the inter-disciplinary talent who understand both economic, legal, business knowledge and various policies, and have the ability of communication and coordination and the spirit of technology innovation management.

\subsection{Establish and perfect intermediary service system and increase the docking efficiency of technology market.}

Give full play to the role of the existing technology intermediary service platform, pay close attention to the international and domestic technology market, understand the needs of enterprises, scientific research institutions and universities in time, strengthen the digestion, absorption and innovation of the imported technology, implement the localization strategy of major technical equipment; give full play to the basic role of the technology intermediary market in the optimal allocation of scientific and technological resources and the role of the link and bridge in the transformation of scientific and technological achievements. Focus on improving its professional service level and its influence in the industry; give full play to the role of the network and information market, build a one-stop and networked technology transfer public service system covering the whole process of technology transfer. Give full play to the role of University Science and Technology Park and other institutions of university research achievements transformation, strive to provide services for enterprises with technical consulting, personnel training and other aspects, and effectively improve the ability of enterprises to carry technology transfer. (Li, 2006)

\section{CONCLUSIONS}

Twenty-first Century is an era when the economic globalization and knowledge economy is developing rapidly and when the role of knowledge flow and technological innovation is becoming more and more important. With the raising of "One Belt and One Road" policy, the cooperation between China and CEE will further deepen. Technology transfer, as an important means to promote technology innovation and technology progress, is bound to experience a new development opportunity. (Hu, Liang, \& Su, 2015) The corresponding measures and suggestions put forward on the current situation and existing problems of China-CEEC technology transfer platform has an important guiding role to effectively carry out scientific and technological cooperation with CEEC, promote the transformation of scientific and technological achievements in China-CEE, and promote technological reform of enterprises and the technological progress of the industry.

\section{WORKS CITED}

Chenhai, Z., \& Peizhong., C. (2007). Domestic Technology Transfer Platform Construction Situation Analysis. Taiyuan science and technology(11), 4-10.

Hu, H., Liang, G., \& Su, H. (2015). Research on the Construction and Development Mode of ChinaASEAN Technology Transfer platform. Southeast Asia(5), 8-10.

Jinyi, Z. (2012). The Main Body Analysis and Mode Research of Technology Transfer in China. Science and Technology Information(3), 100-100.

Li, H. (2006). China's Technology Transfer Status and Development Proposals. Enterprise Reform and Management, 1, 30-31. 
Zheng, X., Huang, N., \& Hou, H. (2009). Studies on the Technology Transformation Platform of Provincial Research Institutions in Guangdong Province. Science and Technology Management Research, 29(7), 237-239.

Received for publication:

11.04.2018.

Revision Received:

17.07.2018.

Accepted for publication:

05.09.2018.

Kako citirati ovaj rad? / How to cite this article?

Style - APA Sixth Edition:

Hu, D., \& Wang, B. (2018, 10 15). The Research on the Construction of Ningbo China-CEE Technology Transfer Platform. (Z. Čekerevac, Ed.) FBIM Transactions, 6(2), 32-43. doi:10.12709/fbim.06.06.02.04

Style - Chicago Sixteenth Edition:

Hu, Danjuan, and Bo Wang. 2018. "The Research on the Construction of Ningbo China-CEE Technology Transfer Platform." Edited by Zoran Čekerevac. FBIM Transactions (MESTE) 6 (2): 32-43. doi:10.12709/fbim.06.06.02.04.

Style - GOST Name Sort:

Hu Danjuan and Wang Bo The Research on the Construction of Ningbo China-CEE Technology Transfer Platform [Journal] // FBIM Transactions / ed. Čekerevac Zoran. - Beograd : MESTE, 1015 , 2018. - 2 : Vol. 6. - pp. 32-43.

Style - Harvard Anglia:

Hu, D. \& Wang, B., 2018. The Research on the Construction of Ningbo China-CEE Technology Transfer Platform. FBIM Transactions, 15 10, 6(2), pp. 32-43.

Style - ISO 690 Numerical Reference:

The Research on the Construction of Ningbo China-CEE Technology Transfer Platform. Hu, Danjuan and Wang, Bo. [ed.] Zoran Čekerevac. 2, Beograd : MESTE, 10 15, 2018, FBIM Transactions, Vol. 6, pp. 32-43. 